\title{
線光源による灯火の不快グレアの抑制
}

\author{
専門会員 入 倉 隆 (芝浦工業大学) 正会員 豊 福 芳 典（交通安全環境研究所）
}

\section{Restraint of Discomfort Glare by Linear Light Source}

Fellow Member Takashi Irikura (Shibaura Institute of Technology) and Member Yoshinori Toyofuku (National Traffic Safety and Environment Laboratory)

KEYWORDS : discomfort glare, linear light source, spatial summation, BCD, signal, aeronautical ground light

\section{1.まえがき}

光源がある大きさ（視角）より大きくなると，観測者の目の位 置における法線照度 (角膜照度) が同じであっても，点光源より 暗く感じられる。これは，視覚の空間的寄せ集め効果により，大 きい光源の中央付近の光は $100 \%$ 明るさに寄与するが, 周辺部に行 くにしたがって，その寄与率は低くなるためである11. 不快グレア においても，角膜照度が同じ場合，大きさ（視角）がある值より 大きくなるにしたがって不快グレアの程度は小さくなる2).

したがって，光源を大きくすることによって，近距離で観測し たときのグレアを抑制することができる，また十分に遠距離で観 測した場合, 視角は小さくなる（点光源と見なせるようになる） ので見え方は角膜照度で決まり, 視認距離は大きさの小さい光源 と変わらない。

一般に，信号灯火などの光源を大きくすることは，経済的な理 由や設置上の問題などにより，困難な場合が多い。しかし，LED や光ファイバーなどを線に配列し，長さを長くすることは比較的 容易である。

今までに，光源の大きさと不快グレアの関係についてはいろい 万と研究 ${ }^{3 / 4)}$ が行われているが, 線光源の長さと不快グレアの関係 については明確にされていない. そこで本研究では, 線光源の快・ 不快限界 (BCD) 輝度について実験を行い, 線光源の不快グレア 抑制に対する有効性について検討した。

\section{2. 実験}

\section{1 装置}

実験は準暗室内において実施した。図 1 に実験装置の概要を示 す。観測距離は $1720 \mathrm{~mm}$ であり，被験者はあご台で頙を固定して観 測を行う. 実験に用いたグレア光源の大きさは, 縦 $3{ }^{\prime}$, 横 $3{ }^{\prime}, 66^{\prime}$, $12^{\prime} ， 24^{\prime} ， 48^{\prime} ， 96^{\prime}$ の 6 種類である.グレア光源は, 八ロゲンラン プにより拡散紙及び開口を通して白色光（色度は $x: 0.43, y$ : 0.41）を照射したものであり，均一輝度の光源である，パルスモー ターで制御される回転型 ND フィルターにより, グレア光源の輝 度は被験者が手元のボタンで連続的に変化させることができる. 視野の輝度は, 点灯する蛍光灯の数の変更, 蛍光管の一部の遮

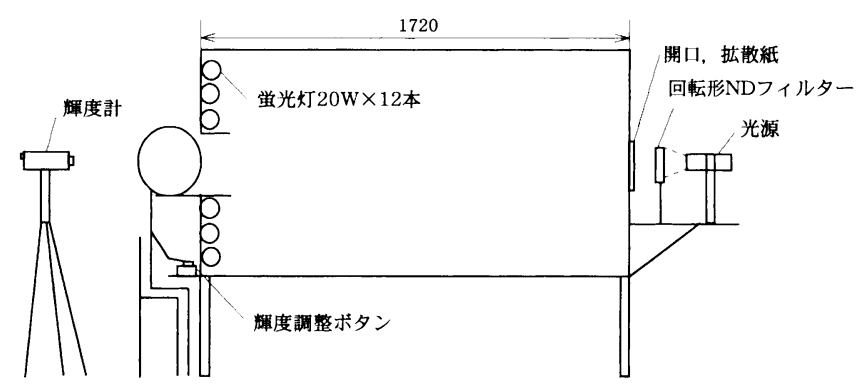

図 1 実験装置

Fig. 1 Scheme of experimental apparatus.

蔽により変化させることができる．また輝度の微調整は点灯電圧 を変化させることによって行う.輝度の調整範囲は $1 \mathrm{~cd} / \mathrm{m}^{2} \sim 1000$ $\mathrm{cd} / \mathrm{m}^{2}$ である. 蛍光灯一本のみ点灯した時, 視野中心 (グレア光源 呈示位置) から $\pm 7.5^{\circ}$ の範囲内に扔ける輝度の一様性 (最小輝度と 最大輝度の比)は，0.93である。今回の実験で用いた視野輝度は， $1.0,10,100 \mathrm{~cd} / \mathrm{m}^{2}$ である.

\section{2 手順}

被験者は23 41歳の男性 5 名である. 実験に先立ち, 各被験者 に BCD 輝度 (不快グレアを感じる光源の輝度の下限值)について 教示するとともに, 数回観測練習を行った. 実験は, 以下の手順 に示すように調整法により行った。

（1）視野輝度が $1.0 \mathrm{~cd} / \mathrm{m}^{2}$ の場合, 被験者はその輝度で約 10 分間の順 応を行う.視野輝度が $10 \mathrm{~cd} / \mathrm{m}^{2}$ 及び $100 \mathrm{~cd} / \mathrm{m}^{2}$ の場合の順応時間は 約 2 分とする.

(2) あご台で䫒を固定する.グレア光源を両眼で注視しながら，グ レア光源の明るさが $\mathrm{BCD}$ 輝度になるように手元のボタンで調 整する.グレア光源の初期設定輝度は $\mathrm{BCD}$ 輝度より十分に低 い輝度とした。また，観測時間の制限は設けなかったが，ほと んどの観測は $1 \mathrm{~min}$ 以内に終えた。

(3) 測定者がグレア光源の輝度を測定する. 測定は, 被験者の目の 位置の近くに設置した輝度計 (Topcon BM-8) を用いて行う.

(4) (3)の測定終了後, 約 $2 \mathrm{~min}$ 経過した後, グレア光源の長さを変 えて(2)〜(3)を繰り返す.グレア光源の長さの呈示順序はランダ 
ムとする．約 $2 \mathrm{~min}$ 経過後に次の観測を行ったのは，観測によ る順応レベルの変動を回復するためと，観測による疲労を少な くするためである。

(5) 視野輝度を変えて(1)〜(4)を繰り返す.

同一条件の観測は各被験者とも 6 回ずつとした。

\section{3. 結果と考察}

光源の長さ (横) と $\mathrm{BCD}$ のきの角膜照度との関係を図 2 に示 す。困中の曲線は最小二乗法によりデータにフィットさせたもの である．破線は傾き 1 の直線である，光源の長さが長くなるにし たがって，曲線の接線の傾きは大きくなっている．光源の長さが 約 $20^{\prime}$ 以上では，その傾きはほぼ 1 となっている。これ以上の長さ においては，光源の長さに比例して，BCDになる角膜照度は大き くなることを示している，すなわち，光源が長くなっても，BCD 輝度は変わらず，長くなった部分の光は不快グレアに奇与してい ないことを意味している，一方，光源の長さが短いときは，曲線 の接線の傾きは 1 より小さく, 光源の長さが長くなるにしたがっ て BCD 輝度は小さくなることを示している.しかし, 光源の長さ が最も短い3付近でも傾きは 0 になっておらず，空間的寄せ集め は完全ではない。

背景輝度が高くなるにしたがって BCDのときの角膜照度は大

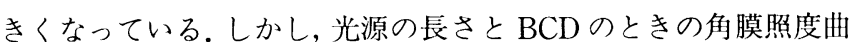
線の関係は同じような傾向を示しており，空間的寄せ集めがなく なる（曲線の接線の傾きが 1 になる）ときの光源の長さもほぼ同 じである。一方，明るさ知覚の実験においては，背景輝度が高く なるにしたがって空間的寄せ集めがなくなるときの光源の大きさ は大きくなることが明らかにされており"，この点が不快グレア の実験と異なる.

ここで，線光源の中心からの距離と不快グレアへの寄与率の関 係について検討してみる，光源中心から $r$ の位置における寄与率

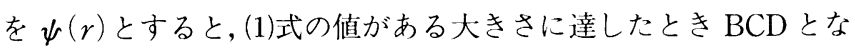
る.

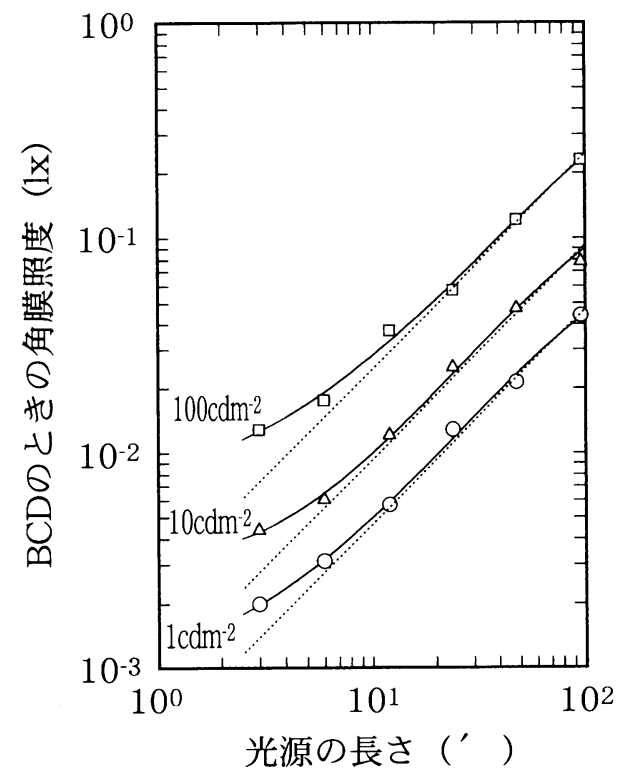

図 2 光源の長さと $\mathrm{BCD}$ のときの角膜照度との関係

Fig. 2 Relation between light source length and BCD illuminance at the eye of observer.
$2 h D^{-2} \int_{0}^{w / 2} \psi(r) L(r) \mathrm{d} r$

ここで， $h$; 光源の縦の長さ (横の長さに比べて十分に短いとす る), $D$; 観測距離, $w$; 光源の横の長さ, $L(r)$; 光源中心から $r$ の位置における輝度。

困 2 の曲線より，背景輝度 $1.0 \mathrm{~cd} / \mathrm{m}^{2}$ における光源中心からの距 離（'）と不快グレアへの奇与率との関係を求めた結果を図 3 に示 す. 四の奇与率は， $0 \sim 1.5^{\prime}$ （光源の長さ $3^{\prime}$ ）における不快グレ アへの寄与率の平均值を 1 とし，その比で示されている. 光源中 心から $2^{\prime}$ の位置で奇与率は約 0.3 , 約 6 'の位置で 0 になってい る.

飛行場の誘導路に設置される誘導路中心線灯を例にとり，観測 距離と角膜照度との関係を求めたものを図 4 に示す。背景輝度は

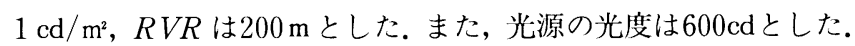
現在, ICAO 等では, CAT-III B における誘導路中心線灯の光度 について議論されており，その中で必要光度を $2000 \mathrm{~cd}$ とる考え 方がある。夜間 (背景輝度 $\left.1 \mathrm{~cd} / \mathrm{m}^{2}\right)$, 低視程 $(R V R 200 \mathrm{~m})$ である ので，光度は30\%夕ップ（3段階光度制御の中間夕ップ）すなわ

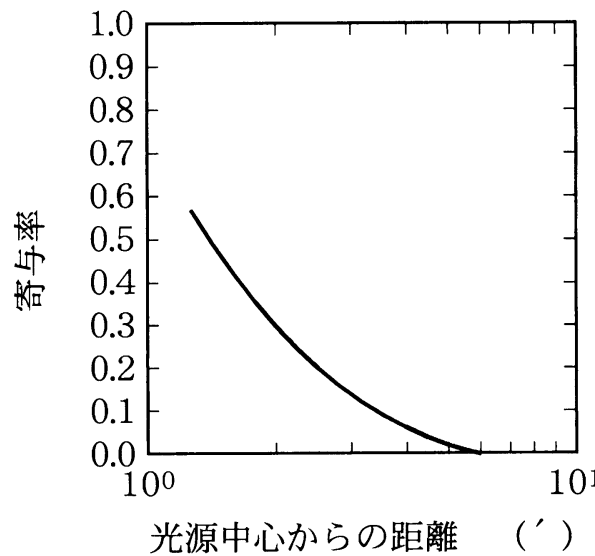

図 3 背景輝度 $1.0 \mathrm{~cd} / \mathrm{m}^{2}$ における光源中心からの距離と不快グレアへの寄与 率との関係

Fig. 3 Relation between distance from the center of light source and element-contribution function in discomfort glare at a background luminance of $1.0 \mathrm{~cd} / \mathrm{m}^{2}$.

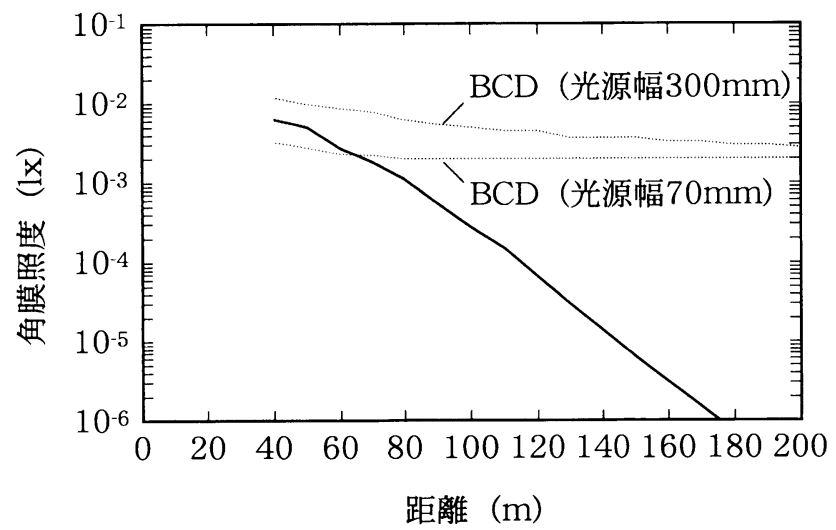

図 4 観測距離と角膜照度との関係

〔図中の点線は, 光源幅 $70 \mathrm{~mm}$ (現用の FM 型灯器) と光源幅 $300 \mathrm{~mm}$ のとき にBCD となる角膜照度を示している」

Fig. 4 Relation between observing distance and illuminance at the eye of observer. 
ち主ビームの最小平均光度を $600 \mathrm{~cd}(2000 \mathrm{~cd}$ の $30 \%$ 光度）とした。 配光は現在の ICAO 基準 (CAT-III) の配光と同じパターンとし, 主ビームの光度を $600 \mathrm{~cd}$ としたものを用いた. 配光曲線の間の光度 は直線で補間した。困中の点線は, 実験結果（図 2) より求めた 光源幅 $70 \mathrm{~mm}$ (現用の FM 型灯器) と光源幅 $300 \mathrm{~mm}$ のときに $\mathrm{BCD}$ と なる角膜照度を示している. $60 \mathrm{~m}$ より近距離では光源幅 $70 \mathrm{~mm} の$ $\mathrm{BCD}$ を超えているが, 光源幅 $300 \mathrm{~mm}$ の $\mathrm{BCD}$ には達していない.つ まり, 現用の FM 型灯器で近距離では不快グレアとなるが, 光源 が $300 \mathrm{~mm}$ 幅の灯器では不快グレアとならない.

この結果より, 光源の横幅を大きくすると, 近距離から見た場 合の視角は大きくなり, 不快グレアになりにくい. しかも，遠距 離から見た場合の光源の視角は小さくなり, 閾值等の見え方は光 源幅の小さな灯器と同じように角膜照度により定まる。すなわち, 光源の横幅を大きくすることにより, 近距離においてまぶしさを 減ずることができ, かつ視認距離は変わらない.

\section{4. まとめ}

線光源の快・不快限界 (BCD) 輝度について実験を行い, 線光 源の不快グレア抑制に対する有効性について検討した。この結果 をまとめると以下のようになる.

（1）背景輝度 $1.0 \mathrm{~cd} / \mathrm{m}^{2}$ における不快グレアへの寄与率は, 線光源中 心から $2^{\prime}$ の位置で約 0.3 , 約 6'の位置で 0 になる。

(2) 航空灯火などの光源の横幅を大きくすることにより,視認距離 は変えずに, 近距離においてまぶしさを減ずることができる.

\section{参 考 文 献}

（1）入倉隆, 谷口哲夫, 青木義郎：いき上レベルにおける視覚 の空間的寄せ集め特性が灯火の明るさ知覚に及ぼす影響, 照学誌, 76-2, pp.90-94 (1993).

(2) 武内徹二, 宮前あつ子，矢野正：閾上の光刺激に対する視 覚の空間的寄せ集め特性，照学全大，p.71（1990）。
(3) C. A. Bennet : Discomfort glare: Concentrated source parametric study of angulary small sources, J. Illum. Engng. Soc. 7-1, pp.2-15 (1977).

（4）田淵義彦, 中村肇, 口石義行, 西村政信, 佐土根範次：中 心視の光源によるグレアの主観評価, 照学誌, 72-10, pp.613 -619 (1988).

（受付日 2001 年 5 月 14 日 $/$ 採録日 2001 年 7 月 5 日）

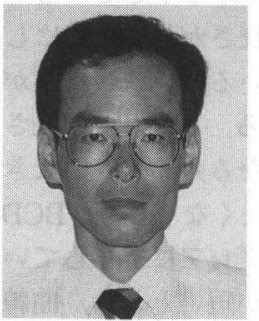

$$
\text { 入倉隆 (専門会員) }
$$

芝浦工業大学工学部電気工学科

1956年 5 月生まれ. 1979年 3 月早稲田大学 理工学部電気工学科卒, 運輸省交通安全公害 研究所を経て，1999年 4 月芝浦工業大学工学 部電気工学科助教授. 博士 (工学). 1994年照明学会研究奨励賞受 賞, 日本光学会, 日本視覚学会, 電気学会, IESNA 会員.

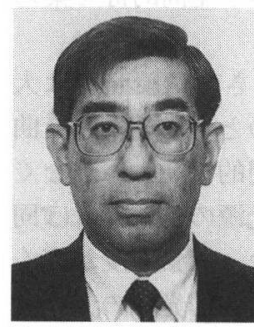

\section{豊福 芳典（正会員）}

独立行政法人交通安全環境研究所交通システ 么部

昭和 24 年 10 月 11 日生まれ，昭和 51 年 3 月京 都大学大学院工学研究科機械工学修士課程修 了, 同年 4 月運輸省入省, 平成 7 年 4 月交通安全公害研究所航焒 研究室長, 平成13年 4 月独立行政法人交通安全環境研究所航空研 究室長, 自動車技術会会員, 日本視覚学会会員, 日本赤外線学会 会員. 